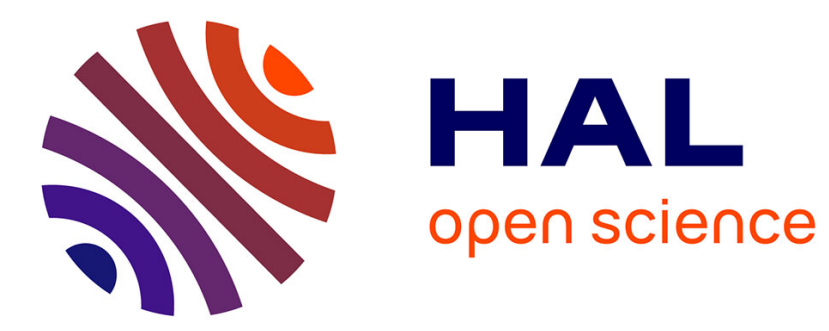

\title{
Particle transport in the central Ionian Sea
}

L. Berline, Andrea M. Doglioli, Anne Petrenko, Stéphanie Barrillon, Boris

Espinasse, Frédéric A.C. Le Moigne, François Simon-Bot, Melilotus Thyssen, François Carlotti

\section{- To cite this version:}

L. Berline, Andrea M. Doglioli, Anne Petrenko, Stéphanie Barrillon, Boris Espinasse, et al.. Particle transport in the central Ionian Sea. EGU, Apr 2021, Vienna, France. hal-03375974

\section{HAL Id: hal-03375974 \\ https://hal.science/hal-03375974}

Submitted on 13 Oct 2021

HAL is a multi-disciplinary open access archive for the deposit and dissemination of scientific research documents, whether they are published or not. The documents may come from teaching and research institutions in France or abroad, or from public or private research centers.
L'archive ouverte pluridisciplinaire HAL, est destinée au dépôt et à la diffusion de documents scientifiques de niveau recherche, publiés ou non, émanant des établissements d'enseignement et de recherche français ou étrangers, des laboratoires publics ou privés. 


\section{Introduction}

PEACETIME cruise in late spring (May 2017)

Northern and center Ionian Sea.

\section{Methods}

- High resolution sampling using MVP mounted with CTD-LOPC-Fluorometer

- Hull mounted ADCP

- Regular CTD stations and underway flow cytometry

- Backward Lagrangian tracking w/geostrophic velocity

- Satellite SST and Chl-a

See Special Issue "Atmospheric deposition in the low-nutrient-low-chlorophyll (LNLC) ocean: effects on marine life today and in the future"

Guieu et al (2020) Biogeosciences, https://doi.org/10.5194/bg-17-5563-2020

See Berline et al (in rev) Long distance particle transport to the central lonian Sea, Biogeosciences https://doi.org/10.5194/bg-2020-481 


\section{mio}

PEACETIME
http://peacetime-project.org/
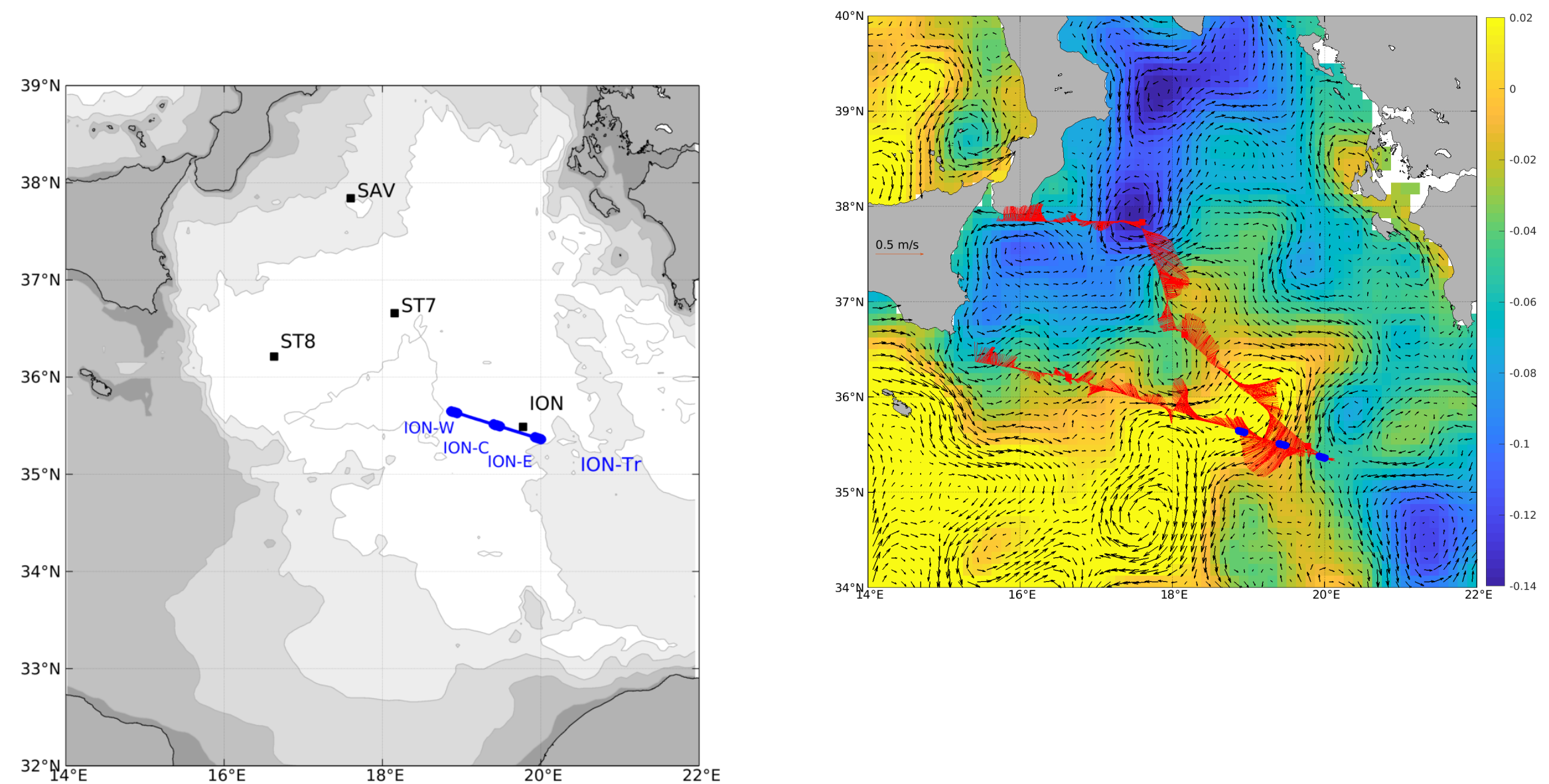


\section{mio}

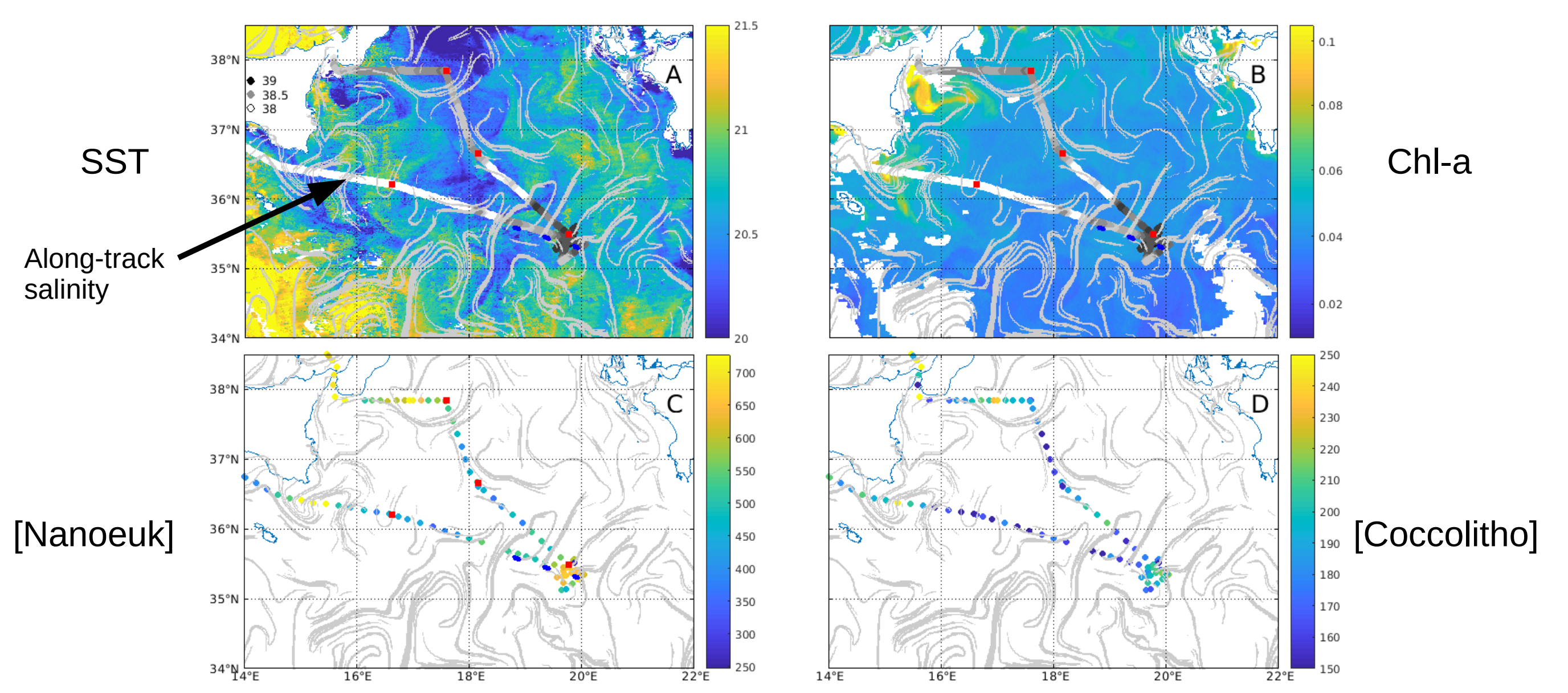




\section{mio}

Along ION-Transect MVP measurements

PEACETIME
http://peacetime-project.org/

IIERMinex
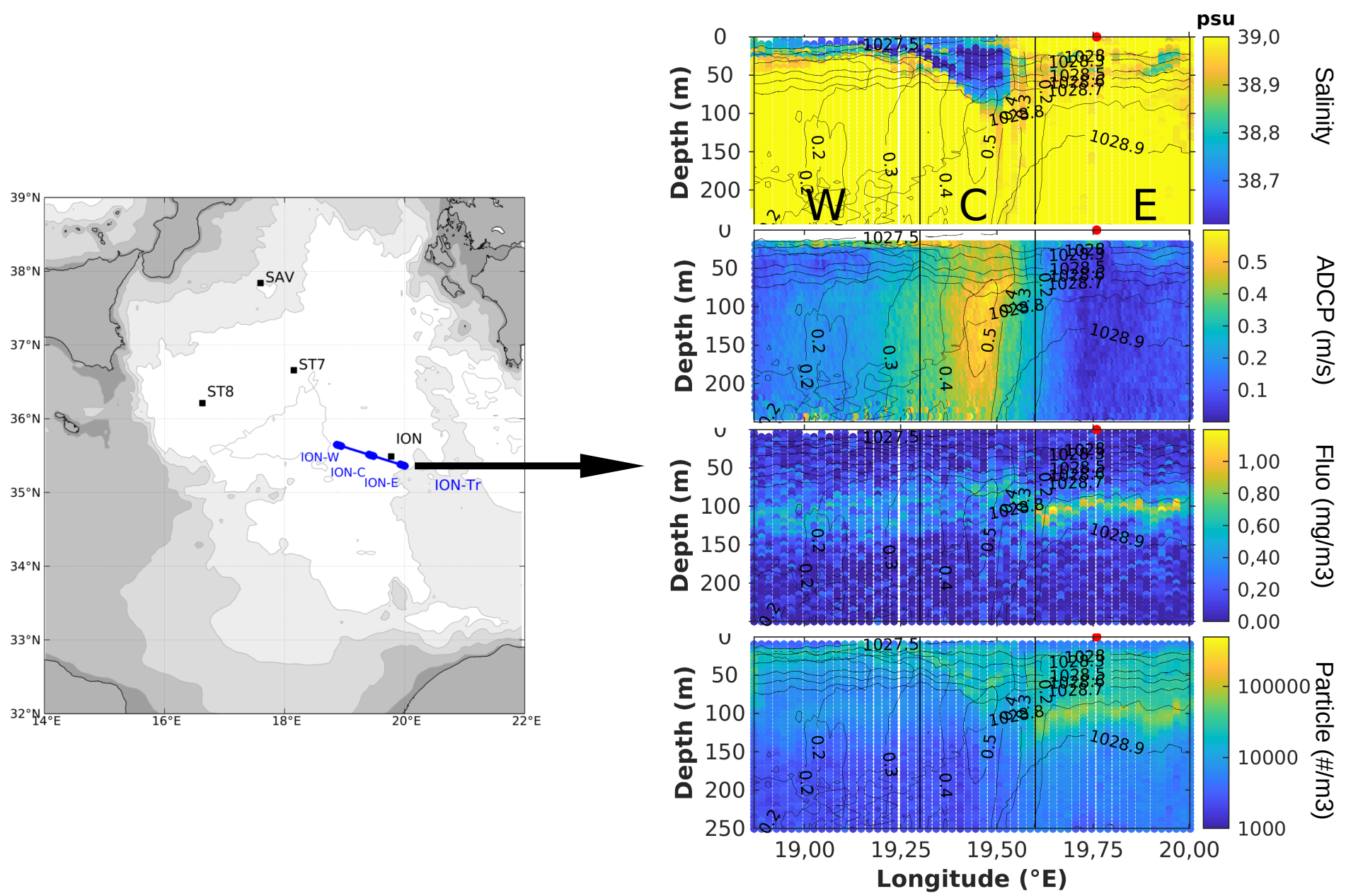


\section{mio}

\section{Profiles}
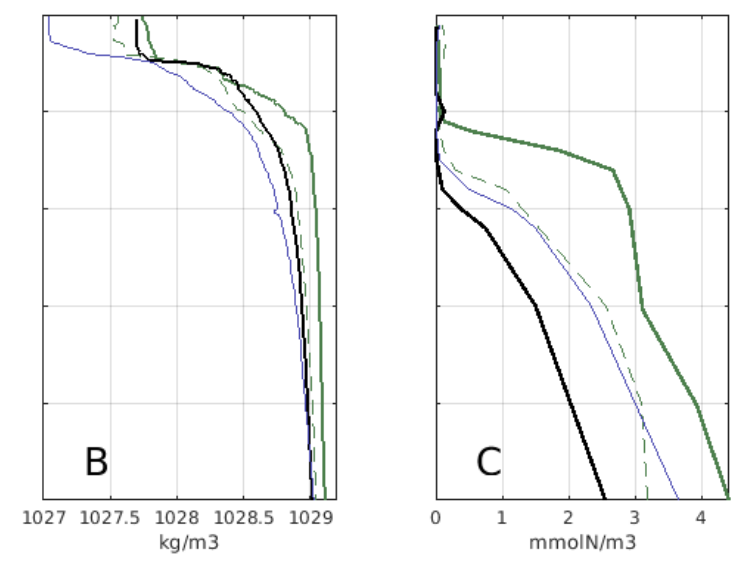

$\mathrm{NO}_{3}$

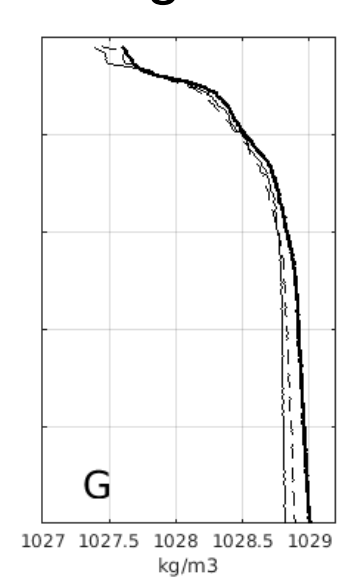

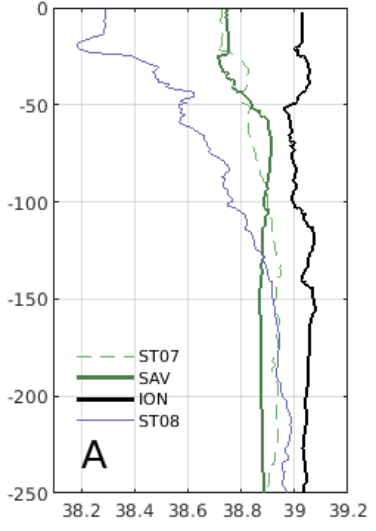

$\mathrm{S}$

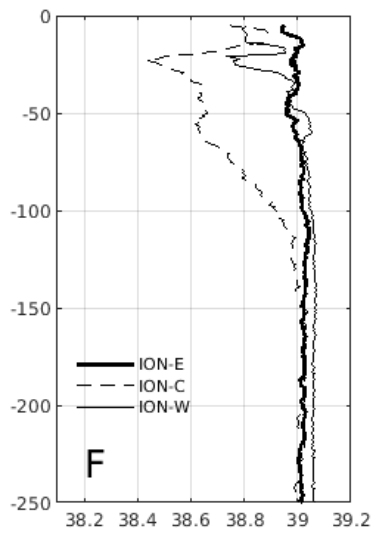

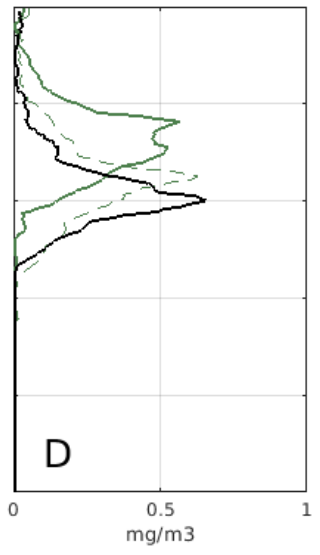

Chl-a

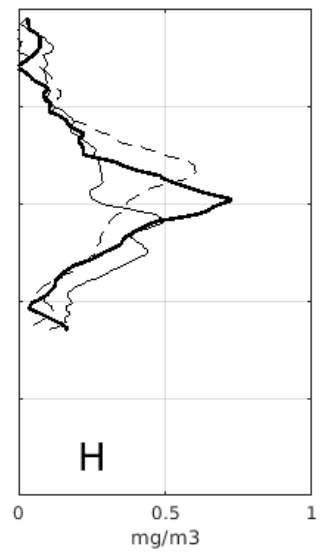

Stations

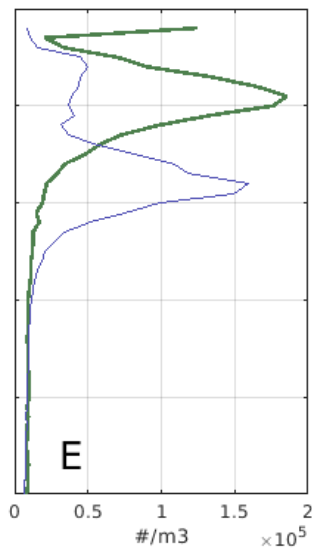

[Particle]

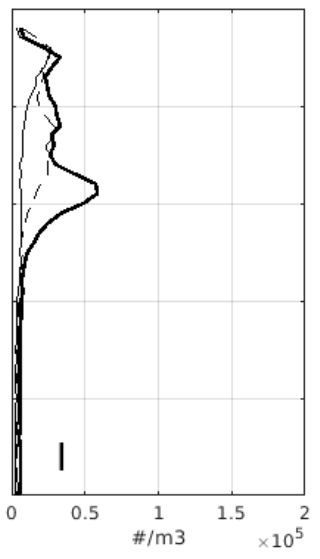

ION Transect 


\section{mio}
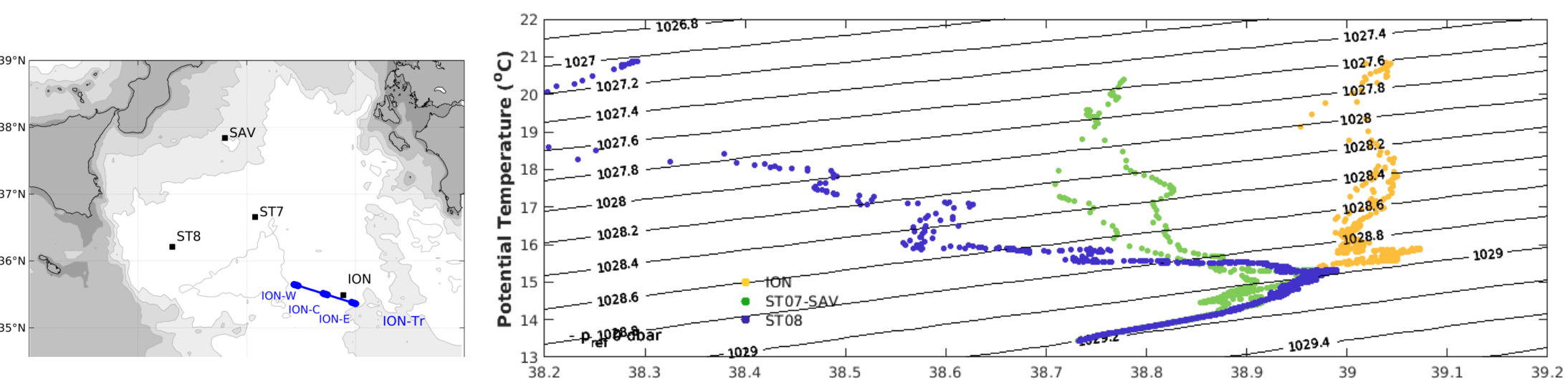

\section{Stations}
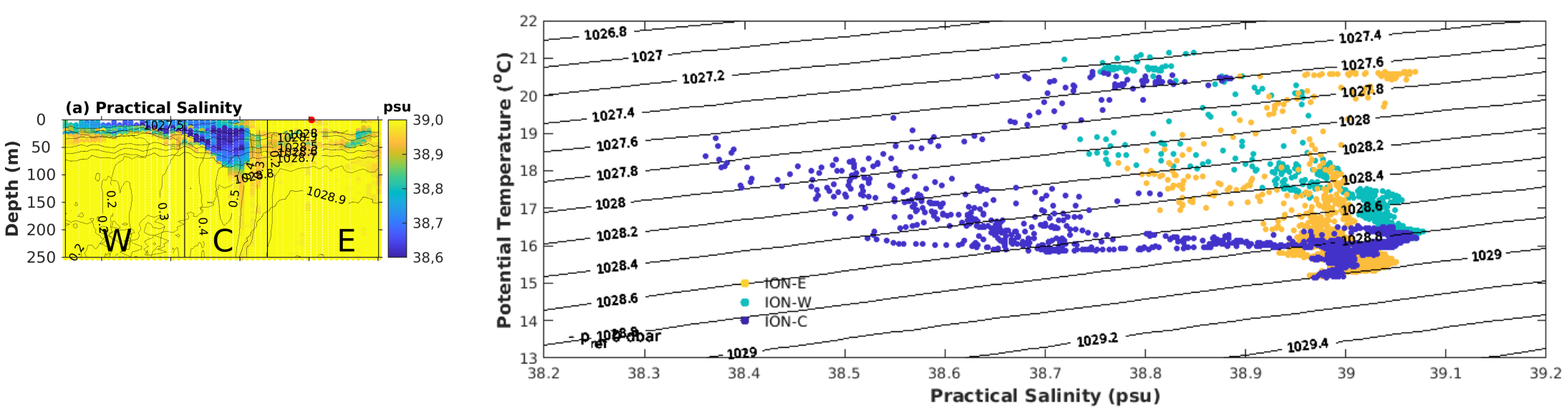

ION Transect 


\section{mio}
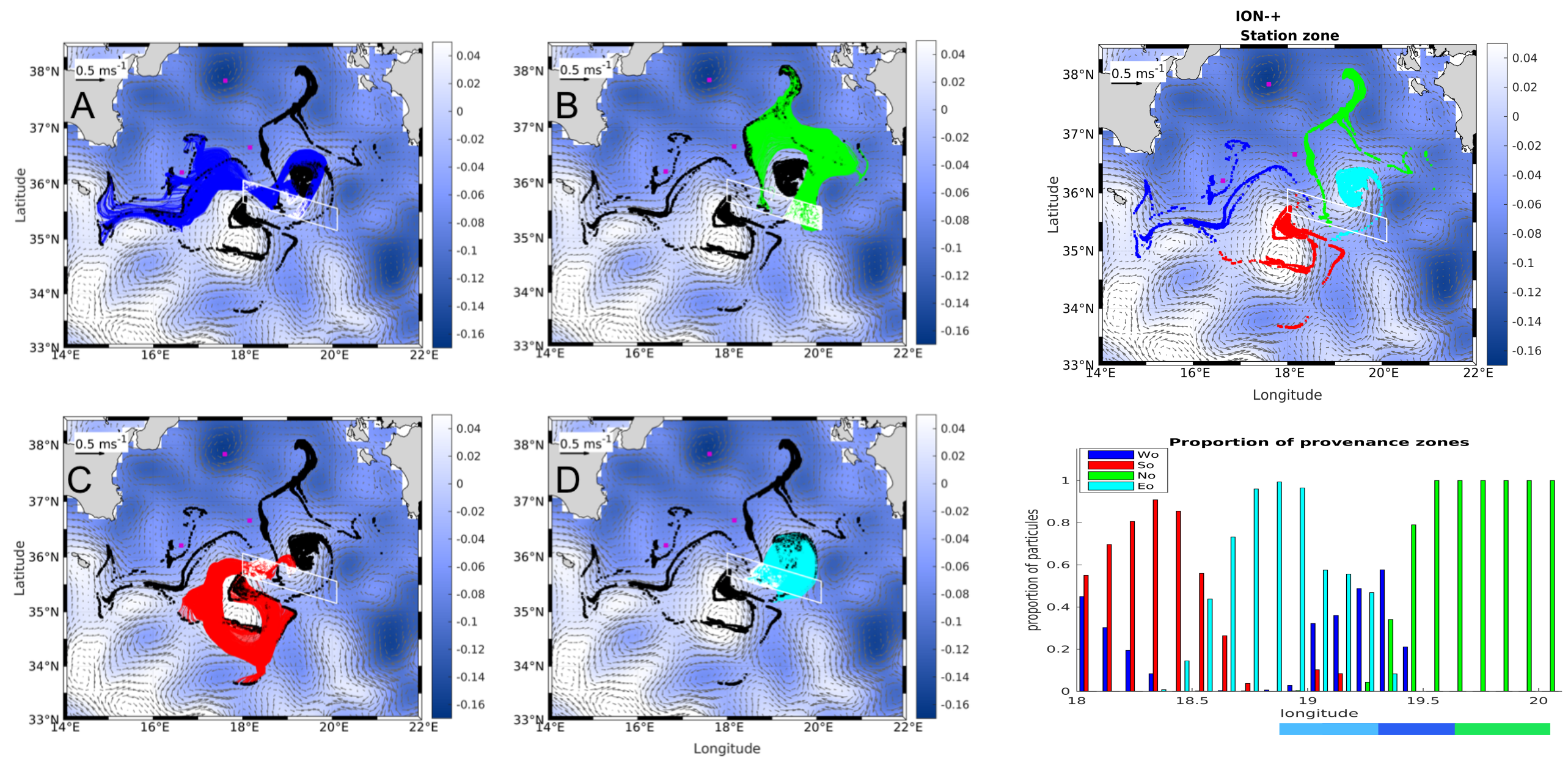


\section{Main findings}

- Strong particle abundance heterogeneity at short scales

- Long distance suspended particle transport as hypothesis

- 3 regions of origin, with different particle [C]:

Western Ionian (Atlantic Water) with moderate particle [C],

Northern Ionian with high particle [C],

Eddy with low particle [C]

- Particle properties (abundance, size distribution) as a proxy for water mass biological history 
Chl-a

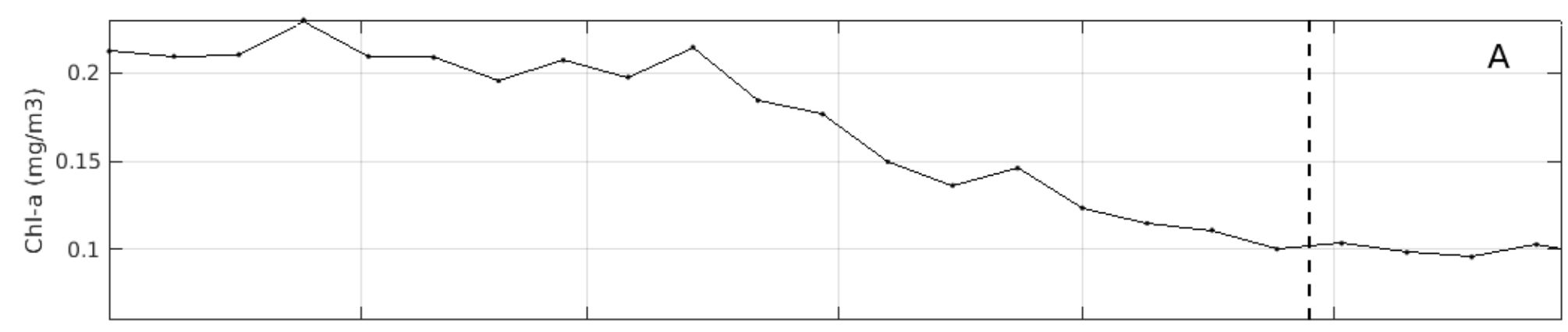

SST

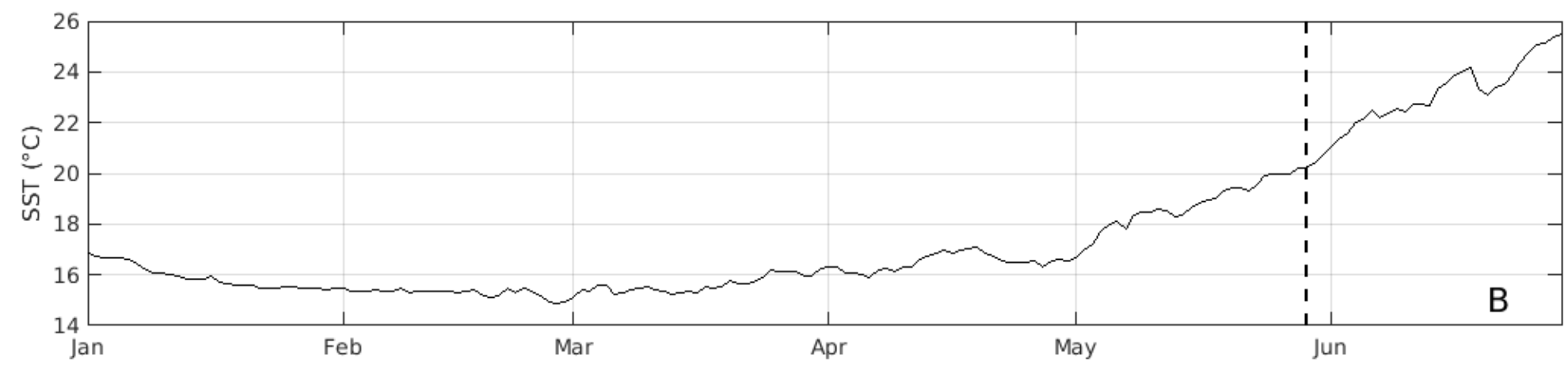

